THE NATURE AND DETERMINANTS OF THE ECONOMIC CURRENCY EXPOSURE OF NONFINANCIAL UK FIRMS

\title{
KATRINA BRADLEY
}

\&

PETER MOLES

ISBN: 


\begin{abstract}
This study examines the sensitivity of sales, profit margins and input costs to exchange rate movements for non-financial, UK firms. The sample is a representative cross-section of larger, publicly-listed firms and is not limited to those directly involved in international trade. Surveyed firms provided data on both the direct and indirect components of economic exposure. As with other studies, we find a statistically significant relationship between a firm's exchange rate sensitivity and the degree to which it sells, sources, or funds itself internationally. Contrary to the theory on economic exposure, only one indirect determinant, that for foreign-based competition, is unambiguously significant. The other indirect effects, the degree of product differentiation, the demand elasticity for a firm's output. and common input currencies for competitors, are not significant in our models. Our examination of the interactive effects suggested by the theory of economic exposure shows no statistical relationship to firm's exchange rate sensitivity. We attribute the weak evidence for competitive effects to the complexities of the indirect determinants of economic exposure at the firm-specific level.
\end{abstract}

Key words: economic exposure, foreign exchange risk, strategic management 


\section{THE NATURE AND DETERMINANTS OF THE ECONOMIC CURRENCY EXPOSURE OF NON-FINANCIAL UK FIRMS}

\section{INTRODUCTION}

In today's world of volatile currencies and increasing global integration and international trade, few companies, if any, remain unaffected by movements in foreign exchange rates. Unexpected changes in exchange rates affect firms' ability to sell abroad, increase the cost of foreign-sourced inputs, and reduce domestic and international competitiveness. This paper reports evidence on UK non-financial firms' economic currency exposure, that is, the impact of currency changes on firms' cash flows. British industry has experienced considerable exchange rate volatility in that, over the last 20 years, sterling has shown periods both of significant relative overvaluation, and of significant undervaluation on a purchasing power basis against its major trading partners. Examples of the overvaluation in sterling include the early 1980s and again following Britain's entry into the European Monetary System in the early 1990s leading up to Black Wednesday and again latterly in the late 1990s. At other times, sterling has been relatively undervalued.

This study seeks to determine the direction, magnitude and effects of economic currency exposure and, in particular, takes into account the indirect or competitive determinants as well as the direct or transactional exposures arising from firms' cross-border trade. As such it both updates and extends studies such as those of Belk and Glaum (1990) and (1994), and Belk (1992). The principal conclusion is that British firms' cash flows are less sensitive to changes in exchange rates than economic exposure theory would suggest.

In seeking to manage exchange rate risk, firms can adopt either operational or financial hedging approaches, or a combination of both (Srinivasulu (1981), Aggarwal and Soenen (1989) and Soenen and Madura (1991)). Operational hedging involves firms in decisions such as the location of production facilities, sourcing of inputs, the nature, features and scope of products, the firm's choice of markets, and 
strategic financial decisions such as the currency denomination of the firm's debt. Moffet \& Karlsen (1994) describe the use of production, financial and marketing policies to manage economic currency exposures as 'natural hedging'. There is evidence for this approach and, insofar as firms can implement appropriate internal solutions, these will be adopted. Broder (1984) in a survey of the top 250 UK listed companies found that less than a quarter of responding firms made operational decisions without considering the effects of currency exposure. Holland (1992) suggests that firms develop a portfolio of foreign exchange risk management methods but that, in the final analysis, many firms select inflexible operational strategies in order to benefit from factor market competitive and comparative advantages. The operational approach was seen as particularly useful for the management of uncertain, long-term future foreign currency cash flows. Edelshain (1995) in a survey of large UK companies found that switching suppliers to take advantage of currency effects was not a widespread practice, with only 4 per cent of firms moving away from strong or strengthening currencies. Dolde (1993) puts forward the case that the advantages of economies of scale in production and distribution and the transaction costs involved in making changes severely limits the feasibility of complete operational hedges.

The most obvious source or determinant of economic currency exposure comes from firms having revenues or costs denominated in foreign currencies. These direct or transaction effects are relatively easy to identify and manage. In addition, firms that also have foreign-based operations will have translation exposures that arise from consolidation. At the same time, there are also a number of indirect effects, which can be just as important and apply both to firms engaged in international business and to domestic firms, but which are substantially more difficult to recognise. This indirect economic currency exposure arises from unexpected movements in foreign exchange rates changing the competitive situation of the firm and which affect the firm's future cash flows (and hence value). Walker (1986) split the impact of currency changes between a 'price' effect and a 'quantity' effect. In his model cash inflows or outputs were subject to changes in export sales revenues, competition in the domestic market from imports, and effects on the domestic market. Cash outflows or inputs were affected by changes in factor and financing costs. Extending 
this approach, Flood and Lessard (1986) provide a framework for relating a firm's competitive position to the economic exposure by making the distinction between competitive and conversion effects. Competitive effects depend on the structure of the firm's markets in which it sells its products and sources its inputs. Firms are categorised as having either high or low sensitivities to changes in exchange rates for costs or prices, or both. Firms which have a mismatch between their cost and price sensitivities, that is exporter and importer firms in their terminology, have the greatest degree of economic exposure.

Building on the Flood and Lessard model and work on indirect exposure by Luerhman (1990), Pringle (1991), George and Schroth (1991), Shapiro (1992), and others, Moffet and Karlsen (1994) characterise economic exposure in terms of functional structure. In essence this is the degree of the firm's international diversification, and its competitive environment, that is the nature of the market in which the firm sells its output. This component is similar to the competitive effect recognised by Flood and Lessard. Moffet and Karlsen's model of economic exposure, which includes both direct and indirect elements, is therefore market exposure, where the actual degree of economic exposure is dependent not only on the firm's structure and operations but also on the competitive responses of rival firms to unexpected changes in the exchange rate. Sundaram and Mishra (1991) and Sundaram and Black (1992) point out that the ability of a firm to adjust prices as a result of unexpected exchange rate movements will depend on the elasticity of demand for their products, which in turn depends on the degree of product differentiation achieved.

The remainder of this paper is set out as follows. We next describe the research design and the hypotheses regarding the effects of economic currency exposure on non-financial firms. We then discuss the nature of the direct and indirect sources of economic exposure and then extend the analysis to include competitive and interactive effects, and then finally summarise and present conclusions from our research. 


\section{RESEARCH}

The research is based on two postal questionnaire surveys of finance directors of about 300 UK publicly-listed non-financial companies undertaken in 1996 and 1997 combined with other corporate information derived from the EXTEL Financial database. The decision to examine only non-financial firms was based on the complexity of foreign currency exposures and risk management processes used by financial firms and the prescriptions of the economic currency exposure theory which discuss firms as producers and consumers.

The survey population consisted of all exchange-listed UK non-financial companies listed in the EXTEL Company Research Database as at November 1995 (629 companies in total). Unlike most previous surveys of corporate currency exposure, the questionnaire was distributed to all companies in the survey population, regardless of the extent of their international involvement. The response rate was 51 per cent for the first survey and 79 per cent for the follow-up. Comparisons of the financial characteristics of respondents with non-respondents did not indicate any significant non-response bias. For example, the average sales of respondents was $£ 710$ million whilst that for non-respondents was $£ 729$ million. The surveys asked firms to rate the effects of foreign exchange movements on sales volumes, profit margins and costs as well as providing information on the proportion of foreign sales, foreign-sourced inputs, foreign competition and production, and foreigncurrency denominated debt. Companies were also asked to indicate the nature of the competitive environment, the proportion of foreign competitors with similar costs, the price elasticity or sensitivity of the firm's products to changes in price, and the degree of product differentiation. Some firms provided additional comments on their responses and a number of follow-up semi-structured interviews were also undertaken.

Previous research on the determinants of economic exposure has been limited in two ways. The first is that they do not take account of the interactions between the explanatory variables. Such interactions are critical, for example, the exposure of a 
company that both sources and sells extensively in foreign markets is likely to be a great deal smaller than that of a similar company which sells in foreign markets but sources its raw materials in its domestic market. The second limitation is that the indirect determinants of economic exposure have not been considered. Also empirical studies, such as that of Jorion (1990), Choi and Prassad (1995), Miller (1998) and $\mathrm{He}$ and $\mathrm{Ng}$ (1998) have concentrated almost exclusively on financially derived ratios such as foreign-to-total sales. They have ignored important determinants such as the extent to which a company's products are differentiated from those of its competitors. In making use of the survey method, we have been able to include and measure these indirect determinants. In that respect it provides an extension and refinement of the approach taken by Miller and Reuer (1998). This uses accounting-derived estimates for competition effects, namely the ratio of exports to sales, foreign assets to total assets, research and development to total sales, and the industry average of foreign sales to total sales as proxies for the competitive environment factors. Our approach allows us to obtain direct measures of these factors. We obtain estimates of respondent firms' sensitivities to the exchange rate for sales volumes, profit margins and input prices and also of the extent of foreign-based investment. Thus a particular firm with low exchange rate sensitivities but has established overseas operations will, in our analysis, be correctly classified. This may not be so in the approach used by Jorion (1990), Donnelly and Sheehy (1996) and Miller and Reuer (1998) an others.

In our analysis we adopt two approaches to examining the constituents of economic currency exposure. The first is a bivariate analysis between the exchange rate sensitivity ratings derived from our survey and a number of company characteristics, which include many indirect determinants of economic exposure. The second approach makes use of ordered logit modelling to investigate the multivariate and interactive relationships between firms' exchange rate sensitivity and its determinants.

A firm's economic currency exposure can be attributed to, one of more of, the nature of the firm's international operations, the nature of its foreign competition, and the nature of the product or service it produces (Booth and Rotenberg, 1990). The extent 
to which a firm sources, sells, finances or produces in foreign markets are the most obvious determinants of its sensitivity to currency effects. The greater the activities of firms in foreign markets, the larger its economic currency exposure is expected to be. We therefore posit there will be a direct positive relationship between the magnitude of a company's economic currency exposure and the extent to which it sells in foreign markets, to the extent that it sources raw materials, or other inputs in foreign markets, to the extent to which a firm manufactures or produces in foreign markets, and to the extent that a firm makes use of foreign currency debt. To examine this issue we used both information derived from the survey and financial ratios.

We also examine the ways economic exposure can be mitigated by firms offsetting exposures and advocated in the literature. The Flood and Lessard (1986) model postulates that the economic currency exposure of a firm that sells in foreign markets will be reduced if it sources its inputs in the same currencies that it receives for its sales. By manufacturing in its foreign markets or employing foreign currency denominated debt a company can also offset the economic exposure from foreign cash inflows. We characterise these as interaction effects. Therefore, the extent to which a company sells its output in foreign markets and the extent to which it sources its inputs in foreign markets, the extent to which it produces or manufactures in foreign markets, and the extent to which it employs foreign-currency denominated debt, is negatively related to the magnitude of its economic currency exposure. We measure these interactive effects as being the product of the scores for each of the individual characteristics.

Compared to the nature of its own foreign operations, the nature of the international competition faced by firms is a more subtle, but still significant, determinant of economic currency exposure. Even companies which do not source or sell in foreign markets may experience significant competition in their domestic markets from foreign-based firms (Lessard and Lightstone 1986). Shapiro (1992) also points out that the extent to which a firm's competitors have costs denominated in similar currencies can be critical in determining the degree of relative exposure. Should the firm and its competitors have costs in the same currencies, a change in exchange 
rates will have a similar effect on all firms operating in a market and the economic exposure of any one firm will be significantly diminished. Therefore, there is a positive relationship between the magnitude of a company's economic exposure and the extent to which its competitors are based in foreign markets but there will be a negative effect to the extent that its competitors have costs which are denominated in the same currencies.

Finally, the extent to which a firm offers a commodity or differentiated product is likely to be an important influence on the sensitivity of its cash flows to currency movements (Sundaram and Black, 1992). If the firm produces a branded product or one with few substitutes, the demand for the product will be relatively inelastic. As a result, such a company is better able to pass-through the effects of exchange rate changes to its customers than an undifferentiated producer. Therefore, there is a positive relationship between the magnitude of a company's economic exposure and the extent to which the demand for its products is sensitive to changes in price and a negative relationship to the extent to which its products are differentiated from those of its main competitors.

\section{DIRECT AND INDIRECT SOURCES OF ECONOMIC CURRENCY EXPOSURE}

In examining the direct effects of economic currency exposure, we looked at the extent to which respondent firms source, sell, manufacturer or finance in foreign markets and their sensitivity to exchange rate effects. Three financial ratios, foreign sales to total sales, foreign profits to total profits and foreign assets to total assets were also used. The correlation between these ratios and the exchange rate sensitivity rankings given by respondents for sales volumes, profit margins and costs are given in Table 1. This shows a strong positive and significant relationship between all the variables. The foreign turnover ratio is more strongly correlated with the exchange rate sensitivity ranking than the foreign profits and foreign assets ratios. In particular, and of note, is the high degree of association between the exchange rate sensitivity of profit margins and the foreign sales to total sales ratio. The survey asked managers to 
indicate the extent to which they engaged in international operations. Only 10 per cent responded that they did not source any inputs abroad and 13 per cent that they did not sell in foreign markets. Around 40 per cent reported that their companies sold forty per cent or more of their output in foreign markets. Approximately two-thirds also have at least some of their production facilities in foreign countries and a similar proportion used an element of foreign currency debt.

Table 1: Correlation matrix: the financial determinants of economic exposure

\begin{tabular}{|c|c|c|c|c|c|}
\hline \multirow{2}{*}{$\begin{array}{l}\text { International } \\
\text { Characteristics }\end{array}$} & \multicolumn{3}{|c|}{$\underline{\text { Sensitivity Rankings }}$} & \multicolumn{2}{|c|}{ Financial Ratios } \\
\hline & $\begin{array}{c}\text { Sales } \\
\text { Volume }\end{array}$ & $\begin{array}{c}\text { Profit } \\
\text { Margin } \\
\end{array}$ & Cost & $\begin{array}{c}\text { Foreign Sales/ } \\
\text { Total Sales }\end{array}$ & $\begin{array}{c}\text { Foreign Profits/ } \\
\text { Total Profits }\end{array}$ \\
\hline $\begin{array}{c}\text { Foreign Sales/ } \\
\text { Total Sales }\end{array}$ & .4494 & .5238 & .3824 & & \\
\hline $\begin{array}{r}\text { Foreign Profits/ } \\
\text { Total Profits }\end{array}$ & .2767 & .3333 & .3520 & .7443 & \\
\hline $\begin{array}{r}\text { Foreign Assets/ } \\
\text { Total Assets }\end{array}$ & .3026 & .3520 & .2668 & .7049 & .7338 \\
\hline
\end{tabular}

Notes: Spearman rank correlation coefficients

All correlation coefficients are significant at the .01 level $\mathrm{N}=298$

Table 2 reports the result of using Goodman and Kruskal's gamma test. This signed test measures both the strength and direction of the relationship, the sign indicating whether a relationship is positive or negative. The results show that there are significant and positive relationships between the exchange rate sensitivity rankings and the sources of direct economic exposure. These relationships strongly support the hypothesis that the more a company sources, sells, finances or produces in foreign markets, the greater firms' exchange rate sensitivity of sales volumes, profit margins and costs. 
Table 2: Direct sources of exchange rate sensitivity

\begin{tabular}{|c|c|c|c|}
\hline $\begin{array}{c}\text { International } \\
\text { Characteristics }\end{array}$ & $\begin{array}{c}\text { Sales Volume } \\
\text { Sensitivity } \\
\end{array}$ & $\begin{array}{c}\text { Profit Margin } \\
\text { Sensitivity } \\
\end{array}$ & $\begin{array}{c}\text { Cost } \\
\text { Sensitivity } \\
\end{array}$ \\
\hline$\%$ Foreign Sales & $\begin{array}{c}.5174 \\
(\mathrm{~g} / \mathrm{se}=9.975)\end{array}$ & $\begin{array}{c}.5807 \\
(\mathrm{~g} / \mathrm{se}=12.622)\end{array}$ & $\begin{array}{c}.4502 \\
(\mathrm{~g} / \mathrm{se}=8.226)\end{array}$ \\
\hline$\%$ Foreign Inputs & $\begin{array}{c}.3138 \\
(\mathrm{~g} / \mathrm{se}=4.724)\end{array}$ & $\begin{array}{c}.4513 \\
(\mathrm{~g} / \mathrm{se}=7.641)\end{array}$ & $\begin{array}{c}.4538 \\
(\mathrm{~g} / \mathrm{se}=7.363)\end{array}$ \\
\hline$\%$ Foreign Production & $\begin{array}{c}.4129 \\
(\mathrm{~g} / \mathrm{se}=.6 .793)\end{array}$ & $\begin{array}{c}.4308 \\
(\mathrm{~g} / \mathrm{se}=11.439)\end{array}$ & $\begin{array}{c}.3798 \\
(\mathrm{~g} / \mathrm{se}=6.332)\end{array}$ \\
\hline$\%$ Foreign Debt & $\begin{array}{c}.4299 \\
(\mathrm{~g} / \mathrm{se}=7.513)\end{array}$ & $\begin{array}{c}.4555 \\
(\mathrm{~g} / \mathrm{se}=8.813)\end{array}$ & $\begin{array}{c}.3602 \\
(\mathrm{~g} / \mathrm{se}=6.225)\end{array}$ \\
\hline
\end{tabular}

To determine the extent of indirect economic currency exposure effects, respondents were asked to rank the influence of foreign competitors, the extent to which competitors costs were in similar currencies, and the sensitivity of the company's main products to changes in price. These were also compared to the sensitivity measures using the Goodman and Kruskal gamma test. The results are presented in Table 3. They indicate that there is a significant positive relationship between exchange rate sensitivity and the extent to which competitors are foreign-based. In contrast, the effect of competitors costs being denominated in the same currency was not found to be significantly related to the exchange rate sensitivity rankings. One explanation for the absence of a relationship may be the result of respondents being unaware of competitors' exposure profiles. That this may be the case is supported by the fact that 11 per cent of respondents did not answer this question. There is also a significant positive relationship between the price sensitivity variable and the exchange rate sensitivity of sales volumes. On the other hand, the relationship between differentiation and sensitivity, whilst significant is of the wrong sign. It was anticipated that this would be negative because the more differentiated a company's 
products, the greater its ability to pass-through the effects of exchange rate movements to its customers. Our results therefore indicate that differentiating a product does not reduce a firm's economic currency exposure.

Table 3: Indirect sources of exchange rate sensitivity

\begin{tabular}{|c|c|c|c|}
\hline $\begin{array}{c}\text { Competitive } \\
\text { Characteristics }\end{array}$ & $\begin{array}{l}\text { Sales Volume } \\
\text { Sensitivity }\end{array}$ & $\begin{array}{l}\text { Profit Margin } \\
\text { Sensitivity }\end{array}$ & $\begin{array}{c}\text { Cost } \\
\text { Sensitivity }\end{array}$ \\
\hline Foreign Competition & $\begin{array}{c}.4529 * * \\
(\mathrm{~g} / \mathrm{se}=8.395)\end{array}$ & $\begin{array}{c}.5576^{* *} \\
(\mathrm{~g} / \mathrm{se}=11.439)\end{array}$ & $\begin{array}{c}.4184 * * \\
(\mathrm{~g} / \mathrm{se}=7.965)\end{array}$ \\
\hline $\begin{array}{l}\text { Foreign Competition } \\
\text { with similar costs }\end{array}$ & $\begin{array}{c}-.0652 \\
(\mathrm{~g} / \mathrm{se}=-.956)\end{array}$ & $\begin{array}{c}.0096 \\
(\mathrm{~g} / \mathrm{se}=.1435)\end{array}$ & $\begin{array}{c}.0342 \\
(\mathrm{~g} / \mathrm{se}=.5066)\end{array}$ \\
\hline $\begin{array}{l}\text { Price Elasticity of } \\
\text { Demand }\end{array}$ & $\begin{array}{c}.1781^{* *} \\
(\mathrm{~g} / \mathrm{se}=2.644)\end{array}$ & $\begin{array}{c}.0374 \\
(\mathrm{~g} / \mathrm{se}=.5490)\end{array}$ & $\begin{array}{c}.1091 \\
(\mathrm{~g} / \mathrm{se}=1.612)\end{array}$ \\
\hline $\begin{array}{l}\text { Degree of Product } \\
\text { Differentiation }\end{array}$ & $\begin{array}{c}.2087 * * \\
(\mathrm{~g} / \mathrm{se}=3.166)\end{array}$ & $\begin{array}{c}.1894 * * \\
(\mathrm{~g} / \mathrm{se}=2.925)\end{array}$ & $\begin{array}{c}.1430^{*} \\
(\mathrm{~g} / \mathrm{se}=2.223)\end{array}$ \\
\hline
\end{tabular}

Our findings for the indirect or competitive effects are less convincing than those for direct effects. One reason for the differences resides in the nature of our data. Our rankings are derived from respondents perceptions of their currency exposure. We use one estimate of exchange rate sensitivity for both direct and indirect exposure. To the extent that direct effects are easily observable and the result of changes in exchange rates, respondents estimates are more heavily weighted in favour of direct effects. Indirect effects, as they involve transmitted effects and which may also be lagged against changes in the exchange rate, are less well perceived. As a result, our measure of the impact of indirect effects are less well correlated with the sensitivity rankings. Another reason may be that indirect effects have a relatively minor impact on firms. While possible, this is not borne out by our individual company case studies. The in-depth interviews with a small number of respondents, although not conclusive, suggest that firms are aware of indirect effects and the impact on their businesses. A final possibility is that our proxy measures for indirect effects are somewhat weak in that they do not fully represent the indirect effects of currency 
exposure. This may be because our first two measures, for foreign competition and the cost of competitors, are relative not absolute whilst the last two are scaled rankings. However, these are also the characteristics of the direct measures and, as discussed earlier, these results confirm the model for direct exposure effects.

\section{INTERACTIVE EFFECTS ON ECONOMIC CURRENCY EXPOSURE}

To examine the interactive effects in determining the overall level of economic currency exposure, an ordered logit model approach was used. Six models were estimated, three using the exchange rate sensitivity of sales volumes (Table 4 shows the $\mathrm{V}$ models) and three for profit margins (Table 5 shows the M models). Model 1 is based on the approach used by Choi and Prasad (1995) and uses only financial ratios as explanatory variables. Model 2 extends model 1 by also incorporating information derived from respondents. Model 3 is the same as model 2 but also includes the three interaction terms: sourcing and selling in the same currencies, selling and manufacturing in foreign markets, and foreign currency denominated debt and foreign sales.

In model 1, the coefficient for the foreign sales to total sales ratio (FS/TS) is positive and significant at the .01 level. These findings are similar to those of Jorion (1990) and Donnelly, and Sheehy (1996) from using stock returns who identified a positive relationship existed between economic currency exposure and the ratio of foreign to total sales. Models 2 and 3 make use of the survey responses. In all four models the proportion of foreign sales to total sales variable is positive and significant at the .01 level. This is consistent with the hypothesis that, as the ratio of foreign sales increases, the exchange rate sensitivity of firms' sales volumes and profit margins also increases. 
Table 4: Ordered Logit Models for Sales Volume Sensitivity to Exchange Rate Movements

\begin{tabular}{|c|c|c|c|c|c|c|c|}
\hline \multirow[b]{2}{*}{ Variable } & \multirow[b]{2}{*}{$P($ sign $)$} & \multicolumn{2}{|c|}{ Model V1 } & \multicolumn{2}{|c|}{ Model V2 } & \multicolumn{2}{|c|}{ Model V3 } \\
\hline & & Coefficient & $z$ & Coefficient & $z$ & Coefficient & $z$ \\
\hline Constant & & 2.118 & $5.31^{\mathrm{a}}$ & -2.2482 & $-3.59^{\mathrm{a}}$ & -5.1567 & $-6.05^{\mathrm{a}}$ \\
\hline FS/TS & $(+)$ & 3.860 & $5.52^{\mathrm{a}}$ & & & & \\
\hline FP/TP & $(+)$ & 1.075 & 1.43 & & & & \\
\hline FNA/TNA & $(+)$ & .367 & .484 & & & & \\
\hline FSALES & $(+)$ & & & .4960 & $3.29^{\mathrm{a}}$ & 1.3101 & $5.79^{\mathrm{a}}$ \\
\hline FINPUTS & $(+)$ & & & -.1748 & -1.19 & .3766 & 1.08 \\
\hline FPROD & $(+)$ & & & -.0051 & -.04 & .6324 & 1.50 \\
\hline FDEBT & $(+)$ & & & .1787 & $1.99^{\mathrm{b}}$ & .4954 & $1.73^{c}$ \\
\hline FCOMP & $(+)$ & & & .0723 & .63 & -.0040 & -.04 \\
\hline CCOMP & $(-)$ & & & -.0708 & -.77 & -.0920 & -.95 \\
\hline SENSITIV & $(+)$ & & & .2873 & $2.56^{\mathrm{a}}$ & .2736 & $2.37^{\mathrm{b}}$ \\
\hline DIFFER & $(-)$ & & & .1192 & 1.05 & .1736 & 1.45 \\
\hline FSA*FIN & $(-)$ & & & & & -.1378 & -1.51 \\
\hline FSA*FPROD & $(-)$ & & & & & -.1215 & -1.12 \\
\hline FSA*FDEBT & $(-)$ & & & & & -.0816 & -1.19 \\
\hline \# obs & & 273 & & 252 & & 252 & \\
\hline Pseudo $\mathrm{R}^{2}$ & & .17 & & .24 & & .29 & \\
\hline $\log L$ & & -343.13 & & -307.97 & & -297.01 & \\
\hline$\chi^{2}$ & & $57.24(\mathrm{df}=3$ & $\mathrm{p}=.000)$ & $80.10(\mathrm{df}=8$ & $\mathrm{p}=.000)$ & $102.02(\mathrm{df}=11$, & $\mathrm{p}=.000)$ \\
\hline$\mu 1$ & & 1.3012 & & 1.4152 & & 1.5312 & \\
\hline$\mu 2$ & & 2.9114 & & 3.2112 & & 3.3561 & \\
\hline$\mu 3$ & & 4.6943 & & 5.0235 & & 5.1844 & \\
\hline
\end{tabular}

\footnotetext{
Notes:

FS/TS $\quad=$ Foreign Sales/Total Sales ratio (Extel Database data)

FP/TP $\quad=$ Foreign Profit Before Tax/Total Profit Before Tax (Extel Database data)

FNA/TNA $\quad=$ Foreign Net Assets/Total Net Assets (Extel Database data)

FSALES $\quad=$ Foreign Sales/Total Sales

FINPUTS $\quad=$ Foreign Inputs/Total Inputs

FPROD $\quad=$ Foreign Production/Total Production

FDEBT $\quad=$ Foreign Debt/Total Debt

FCOMP $\quad=$ Foreign Based Competition/Total Competition

CCOMP $=$ Proportion of competitors with costs denominated in same currencies

SENSITIV = Sensitivity of demand for company's products to changes in price

DIFFER $\quad=$ Extent to which company's products are differentiated from competitors'

FSA*FIN $\quad=$ Interaction variable: Foreign Sales \& Foreign Inputs

FSA*FPROD = Interaction variable: Foreign Sales \& Foreign Production

FSA*FDEBT = Interaction variable: Foreign Sales \& Foreign Debt
}

${ }^{\mathrm{a}}=$ significance level $<.01 \quad{ }^{\mathrm{b}}=$ significance level $<.05 \quad{ }^{\mathrm{c}}=$ significance level $<.10$

Dependent variable is sales volume exchange rate sensitivity

Parentheses following each of the variable names indicates the hypothesised direction of the relationship 
Table 5: Ordered Logit Models for Profit Margin Sensitivity to Exchange Rate Movements

\begin{tabular}{|c|c|c|c|c|c|c|c|}
\hline \multirow[b]{2}{*}{ Variable } & \multirow[b]{2}{*}{$P($ sign $)$} & \multicolumn{2}{|c|}{ Model MI } & \multicolumn{2}{|c|}{ Model M2 } & \multicolumn{2}{|c|}{ Model M3 } \\
\hline & & Coefficient & $z$ & Coefficient & $z$ & Coefficient & $z$ \\
\hline Constant & & 3.373 & $8.02^{\mathrm{a}}$ & -1.6540 & $-2.87^{\mathrm{a}}$ & -3.632 & $-4.33^{\mathrm{a}}$ \\
\hline FS/TS & $(+)$ & 4.594 & $6.40^{\mathrm{a}}$ & & & & \\
\hline $\mathrm{FP} / \mathrm{TP}$ & $(+)$ & 1.479 & $2.06^{\mathrm{b}}$ & & & & \\
\hline FNA/TNA & $(+)$ & -0.071 & -0.97 & & & & \\
\hline FSALES & $(+)$ & & & .4472 & $2.77^{\mathrm{a}}$ & 1.0384 & $4.13^{\mathrm{a}}$ \\
\hline FINPUTS & $(+)$ & & & .1939 & 1.39 & .9499 & $2.94^{\mathrm{a}}$ \\
\hline FPROD & $(+)$ & & & -.2470 & $-1.73^{\mathrm{c}}$ & -.0172 & -.04 \\
\hline FDEBT & $(+)$ & & & .2139 & $2.42^{\mathrm{b}}$ & .2702 & .95 \\
\hline FCOMP & $(+)$ & & & .2990 & $2.55^{\mathrm{b}}$ & .2806 & $2.36^{\mathrm{b}}$ \\
\hline CCOMP & $(-)$ & & & .0433 & .48 & .0248 & .26 \\
\hline SENSITIV & $(+)$ & & & .0285 & .28 & -.0072 & -.07 \\
\hline DIFFER & $(-)$ & & & .0018 & .02 & .0040 & .04 \\
\hline FSA*FIN & $(-)$ & & & & & -.1897 & $-2.07^{\mathrm{b}}$ \\
\hline FSA*FPROD & $(-)$ & & & & & -.0353 & -.32 \\
\hline FSA*FDEBT & $(-)$ & & & & & -.0146 & -.21 \\
\hline \# obs & & 274 & & 253 & & 253 & \\
\hline Pseudo $\mathrm{R}^{2}$ & & .24 & & .31 & & .33 & \\
\hline $\log L$ & & -373.83 & & -329.76 & & -322.84 & \\
\hline$\chi^{2}$ & & $86.52(\mathrm{df}=3$ & $\mathrm{p}=.000)$ & $111.26(\mathrm{df}=8$ & $\mathrm{p}=.000)$ & $125.12(\mathrm{df}=$ & $\mathrm{p}=.000)$ \\
\hline$\mu 1$ & & 1.3496 & & 1.5030 & & 1.6132 & \\
\hline$\mu 2$ & & 2.7824 & & 3.1013 & & 3.2188 & \\
\hline$\mu 3$ & & 4.4213 & & 4.8973 & & 4.99193-4 & \\
\hline
\end{tabular}

\footnotetext{
Notes:

FS/TS $\quad=$ Foreign Sales/Total Sales ratio (Extel Database data)

FP/TP $\quad=$ Foreign Profit Before Tax/Total Profit Before Tax (Extel Database data)

FNA/TNA $\quad=$ Foreign Net Assets/Total Net Assets (Extel Database data)

FSALES $\quad=$ Foreign Sales/Total Sales

FINPUTS $\quad=$ Foreign Inputs/Total Inputs

FPROD $\quad=$ Foreign Production/Total Production

FDEBT $\quad=$ Foreign Debt/Total Debt

FCOMP $\quad=$ Foreign Based Competition/Total Competition

CCOMP $=$ Proportion of competitors with costs denominated in same currencies

SENSITIV = Sensitivity of demand for company's products to changes in price

DIFFER = Extent to which company's products are differentiated from competitors'

FSA*FIN $\quad=$ Interaction variable: Foreign Sales \& Foreign Inputs

FSA*FPROD = Interaction variable: Foreign Sales \& Foreign Production

FSA*FDEBT = Interaction variable: Foreign Sales \& Foreign Debt
}

${ }^{\mathrm{a}}=$ significance level $<.01 \quad{ }^{\mathrm{b}}=$ significance level $<.05 \quad{ }^{\mathrm{c}}=$ significance level $<.10$

Dependent variable is profit margin exchange rate sensitivity

Parentheses following each of the variable names indicates the hypothesised direction of the relationship 
The variable for the proportion of foreign sourced inputs (FINPUTS) performs poorly. It has the right sign, except for model V2 which has a negative coefficient, but is only significant in model M3. The coefficient for foreign debt (FDEBT) is significant in both models 2 and V3 with the correct sign. Companies that have a higher proportion of foreign currency denominated debt have sales volumes and profit margins that are more sensitive to changes in exchange rates. In contrast, the foreign production variables (FPROD) is only significant in model M2. The sign on the model is the opposite of that expected. One factor influencing the move to foreign production is a response to sales volumes and profit margin exchange rate sensitivities. One likely explanation for the negative coefficient is that companies which have foreign production facilities have as a result been able to reduce their sensitivity to exchange rate effects. As a result, their sales volumes and profit margins are less sensitive to currency movements than pure exporter companies, and hence our results.

\section{COMPETITIVE ENVIRONMENT}

The economic currency exposure model includes the firm's competitive environment or what Moffet and Karlsen (1994) describe as the firm's functional structure. We examined three aspects of a firm's competitive environment with respect to its exchange rate exposure, namely, the degree of foreign competition in a market, the effects of competitors with foreign currency costs, and the degree of product differentiation achieved by firms. The variable measuring the degree to which firms face foreign competition (FCOMP) is significant in models M2 and M3 and of the right sign, but insignificant in models V2 and V3, which are also of the wrong sign. The results from the margin (M) models are therefore consistent with our hypothesis that the more foreign competition, the more exchange rate sensitive firms' sales margins are likely to be. The lack of a significant relationship for the volume (V) models can be explained if firms operating in competitive and undifferentiated markets act as price takers and currency effects are therefore passed-through onto the firm's margin rather than through sales volumes. 
The results for the currency cost profile of competitors (CCOMP) are insignificant. Our results therefore do not support the view that exchange rate sensitivity is reduced if most competitors have similar economic profiles. As discussed in the previous section, one factor driving this result may be simply a lack of awareness by respondents of the currency cost profile of competitors.

Two estimates of a firm's competitive position were obtained. The price elasticity or sensitivity (SENSITIV) of the firm's output together with a measure of product differentiation (DIFFER). The results for price sensitivity were of the right sign and highly significant in models $\mathrm{V} 2$ and $\mathrm{V} 3$, but insignificant and of mixed sign in the margin models. This indicates that the greater the price sensitivity of demand for a company's products, the more sensitive will its sales volumes be to changes in foreign exchange rates. Those for differentiation were insignificant for all the models.

Finally, we examine the effects of operational hedging policies on firms' exposures. To the extent that firms have foreign sales, they may seek to have offsetting inputs, production or debt in the receiving currency. The logit results in model 3 including these interactive terms have the right sign but only one of these terms, that for foreign sales and foreign sourced inputs, is significant.

These results partially support the theoretical economic exposure models, albeit weakly. Perhaps this is not too surprising in that this competitive element of the model is both indirect and of a diffuse and complex interacting nature. Our data and analytic technique is unable to capture these subtle effects. The follow-up interviews did highlight the complexity involved in determining how these competitive factors influenced firms' sensitivity to exchange rate effects. For a given firm, the impact depended not only on the extent to which it sold its products and sourced in foreign markets, but also on such factors as the location of its major competitors and the price sensitivity of its customers. While the surveys did elicit information on these factors, it was difficult to capture their relative significance and subtleties using a ranking procedure. 


\section{CONCLUSIONS}

The economic exposure models proposed by Flood and Lessard (1986), Pringle and Connolly (1993) and others, provide for the existence of both a direct link between a firm's international activities and the degree of currency exposure and also an indirect link resulting from changes in the firm's competitive position. Recent research has tried to determine the importance of these effects. Our results go some way to answering this question. Unlike the econometric analyses used in many empirical studies or individual case studies, we make use of a large survey sample coupled to other financial and business data as our primary source. Using this approach, overall, we find general support these models in the case of non-financial UK firms. The results of our investigation are summarised in Table 6.

Our findings are most conclusive for the direct elements of economic exposure, where all four of the direct sources, increased foreign sales, increased foreignsourced inputs, increased foreign-based production and increased foreign-currency denominated debt are linked to higher levels of exchange rate sensitivity for the firms in our sample. All the variables were of the right sign and statistically significant in the bivariate tests and significant in the logit models. There is a significant positive relationship between the exchange rate sensitivity of firms in our sample and the extent to which they sell, source, produce, or finance in foreign markets. This confirms the findings of previous research in this area by demonstrating that there is a positive association between the magnitude of a company's foreign operations and its exchange rate exposure. 
Table 6: Elements of economic currency exposure: A summary of the findings

\begin{tabular}{|c|c|c|c|c|}
\hline $\begin{array}{l}\text { Elements of Economic } \\
\text { Currency Exposure }\end{array}$ & $\begin{array}{l}\text { Expected } \\
\text { Direction of } \\
\text { the Sign }\end{array}$ & $\begin{array}{l}\text { Variable } \\
\text { Name }\end{array}$ & $\begin{array}{l}\text { Gamma Tests } \\
\text { (significance and } \\
\text { direction of sign) }\end{array}$ & $\begin{array}{c}\text { Logit Modelling } \\
\text { Models M3 \& V3 } \\
\text { (significance and direction } \\
\text { of sign) }\end{array}$ \\
\hline \multicolumn{5}{|l|}{ Direct Effects } \\
\hline $\begin{array}{l}\text { More foreign sales } \\
\text { increases exposure }\end{array}$ & $(+)$ & FSALES & $\begin{array}{c}\mathrm{V}(+)^{* *}, \mathrm{M}(+)^{* *} \\
\mathrm{C}(+)^{* *}\end{array}$ & $\begin{array}{l}\mathrm{V}(+)^{* *}, \\
\mathrm{M}(+)^{* *}\end{array}$ \\
\hline $\begin{array}{l}\text { More foreign sourced } \\
\text { inputs increases exposure }\end{array}$ & $(+)$ & FINPUTS & $\begin{array}{c}\mathrm{V}(+)^{* *}, \mathrm{M}(+)^{* *} \\
\mathrm{C}(+)^{* *}\end{array}$ & $\mathrm{M}(+)^{* *}$ \\
\hline $\begin{array}{l}\text { More foreign-based } \\
\text { production increases } \\
\text { exposure }\end{array}$ & $(+)$ & FPROD & $\begin{array}{c}\mathrm{V}(+)^{* *}, \mathrm{M}(+)^{* *} \\
\mathrm{C}(+)^{* *}\end{array}$ & NS \\
\hline $\begin{array}{l}\text { More foreign currency- } \\
\text { debt increases exposure }\end{array}$ & $(+)$ & $F D E B T$ & $\begin{array}{c}\mathrm{V}(+)^{* *}, \mathrm{M}(+)^{* *} \\
\mathrm{C}(+)^{* *}\end{array}$ & $\mathrm{~V}(+)^{[\mathrm{a}]}$ \\
\hline \multicolumn{5}{|l|}{ Indirect Competitive Effects } \\
\hline $\begin{array}{l}\text { More foreign-based } \\
\text { competitors increases } \\
\text { exposure }\end{array}$ & $(+)$ & FCOMP & $\begin{array}{c}\mathrm{V}(+)^{* *}, \mathrm{M}(+)^{* *} \\
\mathrm{C}(+)^{* *}\end{array}$ & $\mathrm{M}(+)^{*}$ \\
\hline $\begin{array}{l}\text { More competitors with } \\
\text { costs in the same } \\
\text { currencies reduces } \\
\text { exposure }\end{array}$ & $(+)$ & ССОМР & NS & NS \\
\hline $\begin{array}{l}\text { Higher elasticity of } \\
\text { demand increases exposure }\end{array}$ & $(+)$ & SENSITIV & $\mathrm{V}(+) * *$ & $\mathrm{~V}(+)^{*}$ \\
\hline $\begin{array}{l}\text { More differentiation in } \\
\text { product reduces exposure }\end{array}$ & $(-)$ & DIFFER & $\begin{array}{c}\mathrm{V}(+)^{* *}, \mathrm{M}(+)^{* *} \\
\mathrm{C}(+)^{* *}\end{array}$ & NS \\
\hline Interactive Effects & & & & \\
\hline $\begin{array}{l}\text { Foreign sales + foreign- } \\
\text { sourced inputs reduces } \\
\text { exposure }\end{array}$ & $(-)$ & $F S A * F I N$ & N/A & $\mathrm{M}(-)^{*}$ \\
\hline $\begin{array}{l}\text { Foreign sales }+ \text { foreign- } \\
\text { based production reduces } \\
\text { exposure }\end{array}$ & $(-)$ & $\begin{array}{c}F S A * F P R \\
O D\end{array}$ & N/A & NS \\
\hline $\begin{array}{l}\text { Foreign sales }+ \text { foreign } \\
\text { currency debt reduces } \\
\text { exposures }\end{array}$ & $(-)$ & $\begin{array}{r}F S A L E S^{*} \\
F D E B T \\
\end{array}$ & N/A & NS \\
\hline
\end{tabular}


[a] - significant at the .10 level for V3, but at the .05 level for V2

Our results for the indirect or competitive effects are less conclusive. We are able to confirm the competitive effects of currency movements on firms having foreignbased competitors, but our results for differentiation effects and common-costs do not accord with the theoretical models. Our results suggest that the indirect sources of economic exposure appear to be less important than direct ones. Our statistical tests reveal only a weak relationship between these factors and exchange rate sensitivity. Of the four indirect sources in our study only two are found to be significantly related statistically to our measure of exchange rate sensitivity. One possible explanation is the nature of our sample in that the companies are not exposed to competitive effects and, unlike previous studies, were not selected ex ante on the basis of their international activities. Whilst this is possible, it seems unlikely. The population is made up of the larger UK, publicly-listed firms. Furthermore, data derived from the survey indicated that 87 per cent sold some or all of their product abroad and 90 per cent sourced some of their inputs in foreign markets.

A more likely effect revealed in the follow-up interviews is that our logit modelling of ordinal scaled data was unable to capture the subtle effects involved. The interviews did provide support at the individual company level for the importance of competitive effects in determining economic currency exposure. Our research therefore highlights the importance of the individual company-specificity of second order effects on competitiveness. This is an area where further studies examining these issues based on case study methods of selected industries would be most valuable. 


\section{References}

Aggarwal, R. and Soenen, L. (1989) Managing persistent real changes in currency values: the roles of multinational operating strategies, Columbia Journal of World Business, 24(3): 60-67

Belk, P. (1992) Foreign exchange risk management in UK multinationals revisited, Loughborough University Business School, Working Paper 1992:23

Belk, P., Bakay, V. and Duangploy, O. (1993) Foreign exchange risk management practices: a comparative empirical analysis of UK and US MNEs Loughborough University Business School, Working Paper

Belk P. and Glaum, M. (1994) A comparative study of foreign exchange risk management in UK and German MNCs, Paper presented at the European Business Conference, University of Nottingham, April, 1994

Belk, P. and Glaum, M. (1990) The management of foreign exchange risk in UK multinationals: an empirical investigation, Accounting and Business Research,. 21(81): 3-11

Bodnar, G. and Gentry, W. (1993) Exchange rate exposure and industry characteristics: evidence from Canada, Japan and the USA, Journal of International Money and Finance, . 12: 29-45

Booth, L. and Rotenberg, W. (1990) Assessing foreign exchange exposure: theory and application using Canadian firms, Journal of International Financial Management and Accounting, 2(1): 1-22

Broder, P.G. (1984) An Empirical Analysis of the Relationship between Prices and Exchange Rates, 1974-82 and An Investigation of the Foreign Exchange Risk Management Function in UK Multinationals, unpublished $\mathrm{PhD}$ thesis, University of Wales Institute of Science \& Technology

Choi, J. and Prasad, A. (1995) Exchange rate sensitivity and its determinants: a firm and industry analysis of US multinationals, Accounting and Business Research, 24(3):, pp 77-88

Dolde, W. (1993) Use of foreign exchange and interest rate risk management in large firms, University of Connecticut, School of Business Administration, Working Paper 93-042, November

Donnelly, R. and Sheehy, E. (1996) The share price reaction of UK exporters to exchange rate movements: an empirical study, Journal of International Business Studies, 27(1): 157-165

Edelshain, D. (1995) British Corporate Currency Exposure and Foreign Exchange Risk Management, unpublished PhD thesis, London Business School 
Flood, E. and Lessard, D. (1986) On the measurement of operating exposure to exchange rates: a conceptual approach, Financial Management, 15: 25-36

George, A. and Schroth, C. (1991) Managing foreign exchange for competitive advantage, Sloan Management Review, 32(2): 105-116

He, J. and L. K. Ng (1998) The foreign exchange exposure of Japanese multinational corporations, Journal of Finance, VIII(2): 733-753

Lessard, D. and Lightstone, J. (1986) Volatile exchange rates can put operations at risk, Harvard Business Review, July-August: 107-114

Levi, M. (1994) Exchange rates and the valuation of firms. In Amihud, Y. and Levich, R. (eds.) Exchange Rates and Corporate Performance, USA: Irwin Professional Publishing

Luehrman, T. (1990) The exchange rate exposure of a global competitor, Journal of International Business Studies, 21(2): 225-242

Miller, K. D. (1998) Economic exposure and integrated risk management, Strategic Management Journal, 19: 497-514

Miller K. D. and J. J. Reuer (1998) Firm strategy and economic exposure to foreign exchange rate movements, Journal of International Business Studies, 29(3): 493-514

Moffet, M. and Karlsen, J. (1994) Managing foreign exchange rate economic exposure, Journal of International Financial Management and Accounting, 5(2): $157-175$

Pringle, J. (1991) Managing foreign exchange exposure, Journal of Applied Corporate Finance , 3(4): 73-82

Pringle, J. \& Connolly, R. (1993) The Nature and causes of foreign currency exposure, Journal of Applied Corporate Finance, 6(3): 61-72

Shapiro, A. C. (1992) Multinational Financial Management (4/e), London: Allyn \& Bacon

Soenen, L. and Aggarwal, R. (1989) Cash and foreign exchange management: theory and corporate practice in three countries, Journal of Business Finance and Accounting, Winter: 599-619

Srinivasulu, S. (1981) Strategic response to foreign exchange risks, Columbia Journal of World Business, 16(1): 13-23 